\title{
ALLEN'S HUMMINGBIRD NESTS IN MEXICO: EXPANSION OF SELASPHORUS SASIN SEDENTARIUS INTO BAJA CALIFORNIA
}

RICHARD A. ERICKSON, LSA Associates, 20 Executive Park, Suite 200, Irvine, California 92614; richard.erickson@lsa-assoc.com

ABSTRACT: Subspecies Selasphorus sasin sedentarius of Allen's Hummingbird has been expanding its range in southern California since the 1960s. Nesting near Tijuana, Baja California, in 2014 and 2015 established the first nesting records for Mexico. The species is likely to expand farther into Mexico, and some local displacement of Anna's Hummingbird (Calypte anna) may be expected.

Although it winters primarily in south-central Mexico, Allen's Hummingbird (Selasphorus sasin) is almost endemic to coastal California during the breeding season (Howell and Webb 1995, AOU 1998). Two subspecies have been described: the smaller migratory nominate sasin, breeding from southwestern Oregon (Marshall et al. 2003) to mainland Ventura County, California, and the larger nonmigratory sedentarius, originally restricted to the Channel Islands (Grinnell and Miller 1944) and subsequently expanding to the nearby mainland (Wells and Baptista 1979). Presumably because of

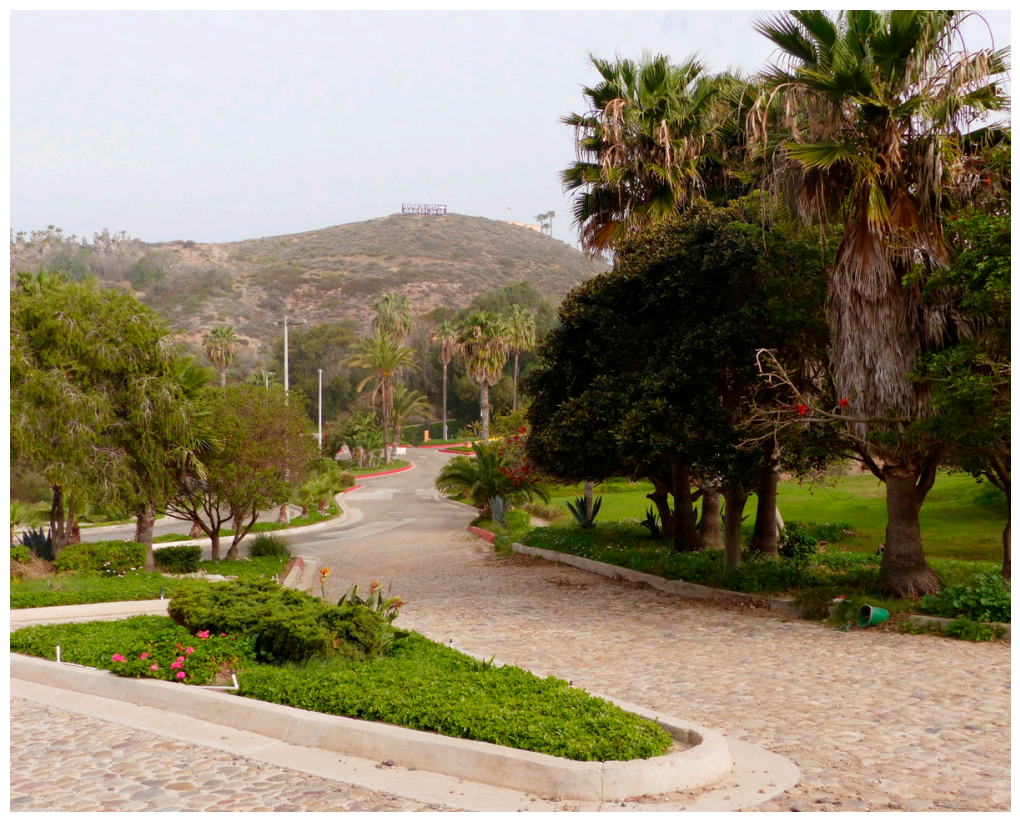

Figure 1. Real del Mar, Baja California, 19 Feb 2015. Allen's Hummingbirds nested in the dark green tree (cf. Ficus rubiginosa) on the right.

Photo by Richard A. Erickson 
its restricted range, Allen's Hummingbird is recognized as a federal "bird of conservation concern" (USFWS 2008) and a "California special animal" (CDFW 2015); the species has not been identified for conservation purposes in Mexico (SEMARNAT 2010).

Unitt (2004) summarized the range expansion of sedentarius onto the California mainland, beginning on the Palos Verdes Peninsula in the 1960s, with nesting first confirmed in Orange County in 1980 and San Diego County in 2001. The subspecies is now common essentially throughout coastal San Diego County (Unitt and Hargrove in press).

\section{HISTORICAL STATUS ON THE BAJA CALIFORNIA PENINSULA}

Although often confused with the more northerly Rufous Hummingbird ( $S$. rufus), which also migrates through northwest Mexico, Allen's Hummingbird has long been known as a spring and fall transient through the state of Baja California (Grinnell 1928). Phillips (1975) reviewed Allen's Hummingbird in Mexico, emphasizing the identification challenges presented by this species pair, and accepted no records for the months of April and May, at the height of the breeding season in California. Through the early 2000s, there were still no winter records of Selasphorus hummingbirds for the Baja California Peninsula (Erickson et al. 2001), though a few individuals had been seen into April in the California border region (Unitt 2004). Records through 2013 in eBird/aVerAves (www.ebird.org) and those accumulated since the inception of North American Birds coverage of the Baja California Peninsula in 2000 (see Erickson et al. 2008) match the seasonality outlined by Phillips (1975). On the southern half of the peninsula, Howell et al. (2001) and Erickson et al. (2013) acknowledged identification problems but found no unequivocal records of Allen's Hummingbird for Baja California Sur at any time of year.

Over the past 15 years, I have made repeated observations of birds at Real del Mar (Figure 1), an upscale private community centered on a golf course and ponds on the coast of Baja California approximately $10 \mathrm{~km}$ south of the California border. Among the vast ornamental plantings is a large hedge of hummingbird-friendly cape honeysuckle (Tecoma capensis). Often accompanied by others, I made 48 visits to this location from 2001 to 2013, and Mark J. Billings made an additional three during the same period. The visits occurred in every month of the year except February, with multiple visits in all of those months except August. We recorded Selasphorus hummingbirds on 23 of those visits, but confirmed Allen's Hummingbird only once: an early spring migrant on 16 January 2006 (M. J. Billings).

\section{RESIDENT ALLEN'S HUMMINGBIRD ARRIVES IN MEXICO}

Since 2010, Selasphorus hummingbirds (a few confirmed as, and most presumed to be, Allen's Hummingbirds) have wintered regularly in ornamental vegetation at scattered locations in coastal Baja California south to Ejido Eréndira, approximately $50 \mathrm{~km}$ south of Ensenada $\left(31.28^{\circ} \mathrm{N}, 116.38^{\circ} \mathrm{W}\right)$, where Matt Sadowski and Ryan M. Abe noted four on 30 December 2012 (N. Am. Birds 67:344, 2013). The first of these wintering birds found was at Real del Mar 30 December 2010 (M. Sadowski pers. comm.). Also in 
2010, the first observation hinting at nesting of Allen's Hummingbird in Mexico was of one unidentified Selasphorus hummingbird at Real del Mar on the unusual date of 15 May (M. J. Billings).

In 2014 I observed one or two male Allen's Hummingbird at Real del Mar on 16 April (displaying), 18 April, and 18 June, along with several female Selasphorus hummingbirds in April. Seven Selasphorus hummingbirds that could not be identified to age or sex were observed on 18 June, and might have included juveniles. I suspected a used nest found on 18 April to belong to Allen's Hummingbird, but comparison of the nest with nests preserved at the Western Foundation of Vertebrate Zoology in Camarillo, California, was inconclusive, as the sympatric Anna's Hummingbird (Calypte anna) could not be eliminated from consideration. The nest (now WFVZ 192408) was located about $2.5 \mathrm{~m}$ off the ground on the underside of the outer branches of an ornamental myoporum tree (Myoporum laetum). Nesting was first confirmed on 6 October 2014. I observed ten Selasphorus hummingbirds on that date, including a female collecting nest material in a patch of Myoporum approximately $150 \mathrm{~m}$ from the April nest tree, but I did not find the nest.

On 19 February 2015 I observed a female Allen's Hummingbird at Real del Mar repeatedly feeding two fledglings in the dead branches of a Myoporum approximately 50 m from the 2014 nest tree (see this issue's inside front cover), and another female constructing a nest approximately 3 $m$ off the ground on the underside of the canopy of an ornamental fig tree (cf. Ficus rubiginosa) approximately $20 \mathrm{~m}$ from the 2014 nest tree. Also seen that day were two male Allen's Hummingbirds and six Selasphorus hummingbirds not identified to species. On 11 April 2015, I saw two male Allen's Hummingbirds and six other Selasphorus hummingbirds, and was surprised to find the Ficus nest still active more than seven weeks after its discovery. A female was actively feeding two nestlings (Figure 2). The used nest was collected on 24 June 2015 and is now WFVZ 194797.

\section{DISCUSSION}

The surge in winter records of Selasphorus hummingbirds in northwest Baja California since 2010 apparently represents the beginning of Allen's Hummingbird colonization of this urbanizing area (Erickson et al. 2013). Given continuing development in that portion of Mexico, and the associated proliferation of ornamental planting, it seems possible that Allen's Hummingbird will eventually colonize the entire California biogeographic region of Baja California, south to El Rosario at approximately $30^{\circ} \mathrm{N}$. This corresponds to the continuing expansion of the subspecies' range in southern California: to the east into San Bernardino (Redlands) and Riverside counties (Clark and Mitchell 2013; www.ebird.org) and to the northwest, apparently into Santa Barbara County (Lehman 2015).

Anna's Hummingbird may suffer some local displacement as Allen's Hummingbird becomes established in Mexico, as the two species overlap broadly in their habitat preferences. Pitelka (1951) studied competition between migratory Allen's Hummingbirds and Anna's Hummingbirds and found the larger Anna's dominant, but he emphasized the advantage conferred by Anna's permanent residency and earlier nesting (traits shared by seden- 


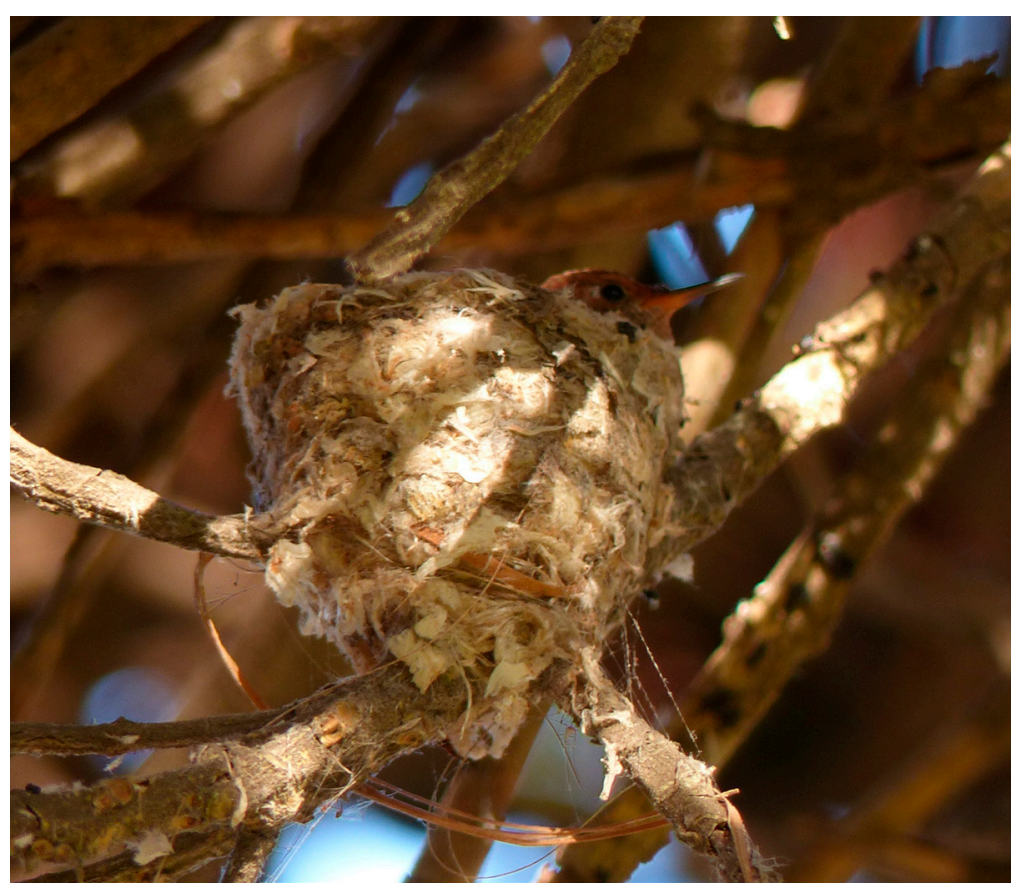

Figure 2. Allen's Hummingbird nest and nestling at Real del Mar, Baja California, 11 April 2015.

Photo by Richard A. Erickson

tarius). Also within the range of migratory Allen's, Legg and Pitelka (1956) found female Anna's dominant over female Allen's, but male Anna's were displaced by male Allen's. Yeaton and Laughrin (1976) studied hummingbirds on Santa Cruz Island during the fall and found that sedentarius excluded Anna's Hummingbirds from its favored territories. Without the constraint of migration, sedentarius has been wildly successful at displacing Anna's from numerous locations it formerly occupied in the Los Angeles area (Kimball L. Garrett pers. comm.), and results from the Los Angeles Christmas Bird Count suggest the same (fide Daniel S. Cooper). This displacement has not yet been detected in San Diego County (Philip Unitt and Paul E. Lehman pers. comm.). It may be too early to compare the two species at Real del Mar, where Anna's Hummingbird still nested in 2015 (WFVZ 194798), but the average number of Anna's recorded on three October visits in 2014-2015 was 3.7, compared to an average of 14.2 (range 5-25) on 16 October visits from 2001 to 2013 (pers. obs.).

The long nesting season observed at Real del Mar is not unprecedented, and may help explain the subspecies' success in colonizing new territory. As early as the 1970s, Wells and Baptista (1979) reported sedentarius attending eggs and/or young in all months of the year except for September and 
October, with nest building observed in October. Although reuse of nests has been reported in this species (Clark and Mitchell 2013), the nesting in Ficus at Real del Mar in both February and April 2015 likely represented a single attempt, the long cycle perhaps due to a protracted nest-building stage or inclement weather, in which nestlings may enter torpor for a few days (C. J. Clark in litt.).

\section{ACKNOWLEDGMENTS}

Many individuals accompanied me during my visits to Real del Mar and elsewhere in Baja California; the observations of Mark J. Billings and Matt Sadowski were particularly helpful in the preparation of this note. Western Foundation of Vertebrate Zoology staff Linnea S. Hall, René Corado, Adam J. Searcy, and Elizabeth Price accessioned the 2014 and 2015 nests into their collection and emphasized the difficulty in distinguishing Allen's and Anna's Hummingbird nests. Daniel S. Cooper, Kimball L. Garrett, Paul E. Lehman, and Philip Unitt discussed hummingbird distribution in southern California. Leo J. Simone assisted with plant identification. Enrique D. Zamora-Hernández, James Bailey, Christopher J. Clark, Brian Myers, Billings, Cooper, and Unitt made helpful comments on drafts of this paper.

\section{LITERATURE CITED}

American Ornithologists' Union (AOU). 1998. Check-list of North American Birds, 7th ed. Am. Ornithol. Union, Washington, D. C.

California Department of Fish and Wildlife, Natural Diversity Database (CDFW). 2015. Special animals list; www.dfg.ca.gov/wildlife/nongame/list.html.

Clark, C. J., and Mitchell, D. E. 2013. Allen's Hummingbird (Selasphorus sasin), in The Birds of North America Online (A. Poole, ed.), no. 501. Cornell Lab. Ornithol., Ithaca, NY; http://bna.birds.cornell.edu/bna/species/501; doi 10.2173/ bna.501.

Erickson, R. A., Carmona, R., Ruiz-Campos, G., Iliff, M. J., and Billings, M. J. 2013. Annotated checklist of the birds of Baja California and Baja California Sur, second edition. N. Am. Birds 66:582-613.

Erickson, R. A., Hamilton, R. A., Carmona, R., Ruiz-Campos, G., and Henderson, Z. A. 2008. Value of perennial archiving of data received through the North American Birds regional reporting system: Examples from the Baja California Peninsula. N. Am. Birds 62:324-331.

Erickson, R. A., Hamilton, R. A., and Howell, S. N. G. 2001. New information on migrant birds in northern and central portions of the Baja California Peninsula, including species new to Mexico. Am. Birding Assoc. Monogr. Field Ornithol. 3:112-170.

Grinnell, J. 1928. A distributional summation of the ornithology of Lower California. Univ. Calif. Publ. Zool. 32:1-300.

Grinnell, J., and Miller, A. H. 1944. The distribution of the birds of California. Pac. Coast Avifauna 27.

Howell, S. N. G., Erickson, R. A., Hamilton, R. A., and Patten, M. A. 2001. An annotated checklist of the birds of Baja California and Baja California Sur. Am. Birding Assoc. Monogr. Field Ornithol. 3:171-203.

Howell, S. N. G., and Webb, S. 1995. A Guide to the Birds of Mexico and Northern Central America. Oxford Univ. Press, Oxford, England.

Legg, K., and Pitelka, F. A. 1956. Ecologic overlap of Allen and Anna hummingbirds nesting at Santa Cruz, California. Condor 58:393-405; doi 10.2307/1365094. 


\section{ALLEN'S HUMMINGBIRD NESTS IN MEXICO}

Lehman, P. E. 2015. The Birds of Santa Barbara County, California, revised edition; https://sites.google.com/site/lehmanbosbc/ (original edition: Vertebrate Museum, Univ. of Calif., Santa Barbara, 1994).

Marshall, D. B., Hunter, M. G., and Contreras, A. L., eds. 2003. Birds of Oregon: A General Reference. Ore. State Univ. Press, Corvallis.

Phillips, A. R. 1975. The migration of Allen's and other hummingbirds. Condor 77:196-205; doi 10.2307/1365790.

Pitelka, F. A. 1951. Ecologic overlap and interspecific strife in breeding populations of Anna and Allen hummingbirds. Ecology 32:641-661; doi 10.2307/1932731.

Secretaría de Medio Ambiente y Recursos Naturales (SEMARNAT). 2010. Norma Oficial Mexicana NOM-059-ECOL-2010, Protección ambiental-Especies nativas de México de flora y fauna silvestres-Categorías de riesgo y especificaciones para su inclusión, exclusión o cambio-Lista de especies en riesgo. Diario Oficial de la Federación, México D. F.

Unitt, P. 2004. San Diego County Bird Atlas. Proc. San Diego Soc. Nat. Hist. 39.

Unitt, P., and Hargrove, L. In press. Southward and downslope extensions of breeding ranges of birds in southern California. Studies of Western Birds 2.

U. S. Fish and Wildlife Service (USFWS). 2008. Birds of Conservation Concern 2008. U.S. Dept. of Interior, Fish and Wildlife Service, Div. Migratory Bird Management, Arlington, VA; www.fws.gov/migratorybirds/pdf/grants/BirdsofConservationConcern2008.pdf.

Wells S., and Baptista, L. F. 1979. Breeding of Allen's Hummingbird (Selasphorus sasin sedentarius) on the southern California mainland. W. Birds 10:83-85.

Yeaton, R. I., and Laughrin, L. 1976. Fall resource division in Santa Cruz Island hummingbirds. Wilson Bull. 88:272-279.

Accepted 28 December 2015 